\title{
Level of Understanding in Political Dynasty of College Students: It's Implication on Equal Access to Public Service
}

\author{
Jacinto Y. Bustamante
}

Nueva Ecija University of Science and Technology, Philippines

\begin{abstract}
This study examined the level of understanding in the political dynasty of 145 college students using a descriptive research design. The questionnaire that was utilized to gather information was a researchermade questionnaire. The findings revealed that the respondents have a high level of understanding with the political dynasty in their places. However, there are practices involved in politics that are not clear to them. On their description of the political dynasty in Nueva Ecija in terms of its advantages/disadvantages, the data showed that the political dynasty would bring more progress and development. The respondents considered the political dynasty as more advantageous to public service. The only disadvantage result of the political dynasty as rated by the respondents were the threats on the constitutional principle on check and balance in the public service and the principle on equal access to public office.
\end{abstract}

Keywords - Financial capability, nepotism, political clan, political dynasty.

\section{INTRODUCTION}

Politics in the Philippines has been under the control of a few notable families (Coronel, Chua, Rimban, \& Cruz, 2007, p.49). It is normal for a politician's son, wife, brother, or another kinsman, to run for the same or other government elective positions. The term coined by Filipinos to describe this practice is "Political Dynasty", the equivalent of an oligarchy in political science. One can trace its roots from the Spanish colonial times where favored families of the mestizo stock or the Illustrados were given responsibilities of Gobernadorcillo or Alcalde. As such, these men have wielded some influence in their communities, and patronage politics was a common undertaking. During the early years of the American rule of the Philippine Islands, these Illustrados joined the democratic process introduced by the Philippine Bill of 1902.During this period, family names such as Cojuangcos, Lopezes, Marcoses, Osmeñas, and Aquinos started to emerge, later on becoming household names. (Coronel, Chua, Rimban, \& Cruz 2007, p.49)

In the 1987 Philippine Constitution, Art II, section 26 provides that "The state shall guarantee equal access to opportunities for public service, and prohibit political dynasties as may be defined by law" (1987, Philippine Constitution).The intention of the lawmaking body in including political dynasty provision in the fundamental laws of the land is to give equal access of every person to public service.

In the system of politics today in the Philippines, brilliant minded potential leaders are being denied to serve the public for the reason of poverty. Most of the time, persons with financial capability and ability to spend money have the opportunity to enter into public service by virtue of the electoral process. Unfortunately, those who have less in life are denied because they cannot afford to spend money to win in the election.

This financial consideration of politicians was evident in all parts of the country including the province where the researcher lives, Nueva Ecija. A province that is quite popular during the local election period since most of the political candidates in the province belongs to strong political clans who are also wealthy people. Even from the time immemorial, it seems to be accepted by the people in the province and they even voted those candidates that belong to the above-mentioned group. 
Most often, Nueva Ecija was headed by political candidates that belong to a political clan. It is therefore a long political practice in the province having leaders under the same family name. Politicians together with their relatives were able to get the vote of the people. Political clans will also be defeated by other political clans. By mentioning the history of politics in the province, it seems that people choose to elect candidates that belong to strong political families thereby creating the continuous existence of the political dynasty.

Despite the fact that people in the province are aware of the prohibition provided by law and the intention of the lawmaking body in the political dynasty, they still choose candidates that belong to the same family to be their political leader. By virtue of these circumstances, it seems that the political dynasty causes a positive effect in Nueva Ecija's political world. This present status of politics in the province contradicts the provision of the constitution. Therefore, it is better to determine what are the underlying reasons why this practice exist as perceived by selected college student residents (Subia, Mangiduyos \& Turgano, 2020).Specifically, it aimed to determine the level of understanding of the student respondents regarding the political dynasty, its advantage and disadvantage, and its implication to equal access to public office.

\section{METHODOLOGY}

This study utilized a descriptive research design. Descriptive research is a fact-finding study with adequate and accurate interpretation of data. It describes with emphasis what actually exists such as the current condition of the phenomenon (Calderon, 2000 as cited by Marcos, et.al., 2020). The respondents of the study were 145 students of Nueva Ecija University of Science and Technology(NEUST) with scientific political background. The respondents were chosen purposively based (Subia, 2018 as cited by Ramos, et.al, 2019) on their knowledge and willingness to participate in the study. The questionnaire that was utilized to gather information was constructed by the researcher. The reliability coefficient of the questionnaire is 0.86designated that it was reliable. Data gathered from the instrument were statistically performed using frequency count, percentage, and weighted mean. The scoring of the responses for the level of conformity of the respondents was: 1.00 to 1.79 Strongly Disagree; 1.80 to 2.59 Disagree; 2.60 to 3.39 Moderately Agree; 3.40 to 4.19 Agree; 4.20 to 5.00 Strongly Agree.

\section{RESULTS AND DISCUSSION}

\section{Level of Understanding on Political Dynasty}

Table 1 presents the level of understanding of the respondents regarding the political dynasty existing in their province.

Table 1. Level of Understanding of the Respondents on Political Dynasty

\begin{tabular}{l|c|c}
\hline \multicolumn{1}{c|}{ Items } & Weighted Mean & Verbal Description \\
\hline 1. It is natural that members of the same family serve the Government. & 3.61 & Agree/High Level \\
\hline 2. Political families having good reputations win the elections. & 3.99 & Agree/High Level \\
\hline 3. Political clans frequently have a good chance of winning in the elections. & 3.59 & Agree/High Level \\
\hline 4. The political dynasty is a constitutional provision. & 3.47 & Agree/High Level \\
\hline 5. The term political dynasty is designed for equal access to public office. & 3.16 & $\begin{array}{c}\text { Moderately } \\
\text { Agree/Moderate Level }\end{array}$ \\
\hline 6. The political dynasty is tantamount to nepotism. & 3.20 & $\begin{array}{c}\text { Moderately } \\
\text { Agree/Moderate Level }\end{array}$ \\
\hline \multicolumn{1}{c|}{ Overall Weighted Mean } & 3.50 & Agree/High Level \\
\hline
\end{tabular}


The table revealed that the respondents have a high level of understanding of the political dynasty in their province. They understood that "political families having good reputations win the elections $(\mathrm{Wm}=3.99)$ " and they believe that "it is natural that members of the same family serve the Government $(\mathrm{Wm}=3.61)$." In contrast, they have a moderate level of understanding with "nepotism" and "political dynasty for equal access to public office". These findings revealed that also the respondents are familiar with the political dynasty in their places, there are terminologies and practices involved in politics which are vague for them.

\section{Respondents' description of the political dynasty in Nueva Ecija in terms of its advantages/disadvantages.}

As shown in Table 2, the respondents describe the political dynasty in Nueva Ecija with the weighted mean of 3.54 with the verbal interpretation of Agree or the respondents most often than not agree to the questions given to them in terms of advantages and disadvantages of a political dynasty. The table also shows the pulse of the respondents as to the question on the political dynasty encourages faithful and honest rendition of public service. The total verbal interpretation of the respondents isagreeing because they obtained a 3.47 weighted mean.

As to the topic of prevention of the electorate to elect those who do not belong to the political clan, the total weighted mean of the respondents in the question is 3.32 with the verbal interpretation of moderately agree.With respect to the question of the political dynasty prevents poor deserving leaders to public office, the respondents answered it as moderately agree with a total weighted mean of 3.29.

The table also shows that respondents are not really convinced that a family of the political clan can manipulate government operations. Their response to that question is moderately agree with a total weighted mean of 3.32. As to the question that the political dynasty breaks the check and balances in the government, the total weighted mean of the respondents is 3.45 or agree.In the improvement of the delivery of public service, the respondents agreed that it is advantageous. However, the respondents strongly agreed that the political dynasty would violate the principle of equal access to public office as guaranteed by the Philippine Constitution as reflected on the table with a weighted mean of 4.48 .

The finding clearly shows that the respondents are clearly not against the political dynasty in the province of Nueva Ecija for the table shows that the perception of the people in the province was they gained more advancement in the system of politics in the province.

Table 2. Advantages and Disadvantages of Political Dynasty

\begin{tabular}{|c|c|c|}
\hline Advantages/Disadvantages of Political Dynasty & Weighted Mean & Verbal Description \\
\hline $\begin{array}{l}\text { 1. The political dynasty ensures an abundant supply of public } \\
\text { servants belonging to the same family. }\end{array}$ & 3.71 & Agree \\
\hline 2. Prohibition of ordinary leaders to access public service. & 3.26 & Moderately Agree \\
\hline 3.Promotion of development of the governmental programs. & 3.60 & Agree \\
\hline 4. Encourages Faithful and honest rendition of public service. & 3.47 & Agree \\
\hline $\begin{array}{l}\text { 5. Prevents the electorate to elect those who do not belong to the } \\
\text { political clan. }\end{array}$ & 3.32 & Moderately Agree \\
\hline 6. Prevents poor deserving leader from public office. & 3.29 & Moderately Agree \\
\hline 7. Breaks check and balance in the government & 3.45 & Agree \\
\hline 8. Allows one family to manipulate government operations. & 3.32 & Moderately Agree \\
\hline 9. Improves delivery of public service. & 3.49 & Agree \\
\hline 10. Violates equal access to the opportunity to public office. & 4.48 & Strongly Agree \\
\hline Overall Weighted Mean & 3.54 & Agree \\
\hline
\end{tabular}




\section{The implication of Political Dynasty on Equal Access to Public Office}

The political dynasty is a constitutional prohibition on serving public office under the same names to the same positions. It restricts equal access to public office to those potential political leaders who have less in life but have a good reputation and intention to serve the public. The Philippine island is a democratic state where the government is a rule of law and has the power to choose their leaders. The political dynasty limits the right of the electorate to choose their leaders for the reason that they cannot choose leaders because only a few can win the election process. Only fortunate candidates can influence the people or even has the power to coerce the electorate to vote them for they have resources to do it. Less privileged candidates are usually left behind. Electorates do not usually recognize names of less privileged politicians for they are underestimated by the electorate with respect to capability and ability to serve the government for the reason of lacking money and reputations. Reputations in politics usually determine by money. Poor politicians are hard to prove their reputations by reason of poverty. Should the government implement the prohibition on the political dynasty the intention of the law on equal access to public office will be attained. Despite the fact that the result of this study favors political clan as an advantage to public service, it doesn't mean that the government should allow the continued existence of political clans to rule the nation. Since the political dynasty is a constitutional prohibition the government should not set aside these prohibitions for the constitution is the real will of the people and the latter are the authors of it. The will of a few should not be regarded if the will of the people will be violated. Electorates are just members of the people. The people are the citizens of the Philippines and it includes those who have just been born, those who have sentenced by final judgment whose right to vote is deprived while serving sentence and those who cannot vote because of age. Therefore, since the constitution is the will of the people it is the highest power in the land than the right of the electorate to vote.

\section{CONCLUSIONS AND RECOMMENDATIONS}

On respondents' level of understanding of the political dynasty, most of them are highly aware and have a high level of understanding that the political dynasty is a constitutional provision. However, they were in doubt as to the true intention of the provision in the political dynasty as to the purpose of equal access to public office. The respondents were also in doubt in the issue of equivalency of dynasty to nepotism. The respondents considered the political dynasty as more advantageous than disadvantageous to public service. The only disadvantage result of the political dynasty as showed were the threats to the constitutional principle on check and balance in the public service and the principle on equal access to public office. Based on the findings and conclusions, the researcher offers the following (Subia, Mina, Diaz, Campos \& Quijano, 2019): other researchers should conduct related research similar to this one with people in the community as respondents. Universities and Colleges must have a participation in information dissemination about the present definitionof political dynasty provision so that the people will not leave behind the belief that persons under the same name are members of the political dynasty.Likewise, a direct and simple (Subia, 2018 as cited by Rodriguez, et.al, 2019) research on the same discipline with more respondents should be conducted to further validate the findings of this study.

\section{REFERENCES}

[1] Art. 2, section 26 of the 1987 Philippine Constitution

[2] Subia, G. S., Mangiduyos, G. P., \& Turgano, J. B. D. (2020). Emergency Preparedness of Novo Ecijanos. Open Journal of Social Sciences, $\quad 8, \quad$ 17-23. https://doi.org/10.4236/jss.2020.83003

[3] Coronel, Chua, Rimban, \& Cruz The Rulemakers Philippine Center for Investigative Journalism (2007); p.49

[4] Subia, G.S. (2018).Comprehensible Technique in Solving Consecutive Number Problems in Algebra. Journal of Applied Mathematics and Physics, 6,447-457. https://doi.org/10.4236/jamp.2018.63041

[5] Ramos, J., et.al.(2019). Leadership Styles of Industrial Engineers in Pottery Industries in Pampanga. International Journal of Advanced Engineering, Management and Science (IJAEMS), Vol-5, Issue-6, https://dx.doi.org/10.22161/ijaems.5.6.10.

[6] Calderon, J.F. (2000). Statistics for educational research simplified. Ermita, Manila: Educational Publishing House.

[7] Marcos, M., et.al. (2020). Entry Competencies and Performance in Mathematics of First-Year Engineering Students in State Universities in Region 3. Test Engineering and Management. ISSN: 0193-4120 Page No. 10148 - 10158.

[8] Subia, G., Mina, J., Diaz, R., Campos, Jr. R.,\& Quijano, G.(2019). Re-Engineering on the Production of Surrogate Feeds for Broiler Chickens (Gallus-Gallus Domesticus): its Effects on Broilers' Live and Carcass Weights and 
Consumption Cost.International Journal of Environment, Agriculture and Biotechnology (IJEAB) Vol-4, Issue-3, http://dx.doi.org/10.22161/ijeab/4.3.4 ISSN: 2456-1878.

[9] Subia, G.(2018). Comprehensible Technique in Solving Consecutive Number Problems in Algebra. Journal of Applied Mathematics and Physics, 6, 447-457. doi:10.4236/jamp.2018.63041.

[10] Rodriguez, R.,et.al.(2019).Correlation between Load Growth and Reliability of an Electric Service Cooperative in the Philippines. International Journal of Advanced Engineering, Management and Science (IJAEMS),Vol-5, Issue-8, https://dx.doi.org/10.22161/ijaems.58.5 ISSN: 2454-1311 